\title{
Pembuatan lilin aroma terapi menggunakan sarang lebah dan ekstrak lemon di Kelurahan Sungai Pagar Kecamatan Kampar Kiri Kabupaten Kampar
}

\author{
Silvia Reni Yenti*, Ahmad Fadli, Zultiniar, dan Sunarno \\ Universitas Riau \\ * silviareniyenti@gmail.com
}

\begin{abstract}
Abstrak. Pengembangan desa merupakan salah satu kepentingan pembangunan Nasional dimana Perguruan Tinggi ikut andil dengan melaksanakan kegiatan Kuliah Kerja Nyata (KUKERTA) dalam bentuk Pengabdian Masyakarat di wilayah yang telah ditentukan. Kampar merupakan salah satu daerah yang memiliki potensi madu sialang terbesar di Provinsi Riau, salah satunya yaitu kelurahan Sungai Pagar, Kecamatan Kampar Kiri Hilir. Pengolahan sarang lebah madu yang tidak diolah secara optimal dapat memberikan inovasi terbaru, yaitu pembuatan lilin aromaterapi dengan menggunakan sarang lebah dan ekstrak lemon. Kegiatan pengabdian ini bertujuan untuk memberikan keahlian ilmu yang baru kepada masyarakat kelurahan Sungai Pagar sebagai salah satu bentuk upaya dalam peningkatan pembangunan Nasional. Serangkaian kegiatannya antara lain penyuluhan atau sosialisasi, pelatihan pembuatan lilin aromaterapi, pengemasan dan pemasaran. Kegiatan ini memberikan respon yang positif dari masyarakat Sungai Pagar dengan dibentuknya kerjasama antara Tim Pengabdian KUKERTA dengan UKM Imbo Kaluang. Luaran yang dihasilkan dari kegiatan pengabdian ini yaitu produk lilin aromaterapi, Buku Teknologi Tepat Guna (TPG), publikasi media massa (cetak dan online) dan publikasi jurnal.
\end{abstract}

Kata kunci: KUKERTA; Kampar; lilin aromaterapi

\begin{abstract}
Village development is one of the national development interests in which universities contribute to the implementation of the Community Work Program (KUKERTA) in the form of Community Service in a designated area. Kampar is one of the areas that has the biggest honey sialang potential in Riau Province, one of which is Sungai Pagar sub-district, Kampar Kiri Hilir sub-district. Honey honeycomb processing that is not processed optimally can provide the latest innovation, namely the making of aromatherapy candles by using honeycomb and lemon extract. This dedication activity aims to provide new knowledge expertise to the community of Sungai Pagar sub-district as one form of efforts in increasing national development. A series of activities include counseling or outreach, training in aromatherapy candle making, packaging and marketing. This activity gave a positive response from the Sungai Pagar community by forming a collaboration between the KUKERTA Community Service Team and Imbo Kaluang UKM. The outputs generated from these community service activities are aromatherapy candle products, Appropriate Technology Book (TPG), mass media publications (print and online) and journal publications.
\end{abstract}

Keywords: KUKERTA; Kampar; aromatherapy candle

To cite this article: Yenti, S. R., A. Fadli, Zultiniar, \& Sunarno. 2019. Pembuatan lilin aroma terapi menggunakan sarang lebah dan ekstrak lemon di Kelurahan Sungai Pagar Kecamatan Kampar Kiri Kabupaten Kampar. Unri Conference Series: Community Engagement 1: 355-361 https://doi.org/10.31258/unricsce.1.355-361

(C) 2019 Authors

Peer-review under responsibility of the organizing committee of Seminar Nasional Pemberdayaan Masyarakat 2019 


\section{PENDAHULUAN}

Pengembangan desa merupakan pilihan yang tepat dan strategis baik untuk kepentingan sebuah perguruan tinggi maupun kepentingan Pembangunan Nasional. Sungai Pagar merupakan salah satu kelurahan yang terdapat di Kabupaten Kampar, Provinsi Riau. Sungai Pagar yang terletak di Kecamatan Kampar Kiri Hilir memiliki masyarakat yang siap untuk menerima perubahan dalam bentuk peningkatan pengetahuan dan keahlian sehingga tujuan kegiatan dari pengabdian masyarakat ini dapat terlaksana dengan baik. Adapun tujuan dari kegiatan pengabdian masyarakat ini selain untuk meningkatkan kualitas sumber daya manusia, kegiatan ini diharapkan kedepannya mampu membantu dalam menunjang ekonomi masyarakat sekitarnya (Rusliadi et al., 2018; Syahza et al., 2018) sehingga peningkatan target pembangunan nasional dapat terealisasikan.

Kampar merupakan salah satu kabupaten yang memiliki potensi produksi madu hutan yang tinggi. Hal ini ditunjukkan dengan adanya kekonsistenan produksi madu hutan yang berasal dari pohon sialang yang berada di kawasan hutan Kampar. Berdasarkan hasil pengamatan yang telah dilakukan, potensi produksi madu yang tinggi tersebut dikarenakan tersedianya secara luas faktor-faktor yang mendukung produktivitas madu hutan, antara lain potensi lebah dorsata yang mencapai ribuan koloni, dukungan lingkungan habitat dan tanaman pakan lebah yang tersedia cukup luas. Berdasarkan data inventarisasi perlebahan hutan yang menunjukkan bahwa kabupaten Kampar termasuk salah satu kabupaten di Provinsi Riau yang memiliki produksi madu hutan terbesar, salah satunya di kelurahan Sungai Pagar, Kecamatan Kampar Kiri Hilir.

Pemanfaatan lebah sialang di kelurahan Sungai pagar sejauh ini hanya untuk diambil madunya dan diperjualbelikan. Potensi lebah hutan yang melimpah belum dioptimalkan oleh masyarakat sebagai inovasi dalam usaha. Salah satu pengoptimalan pemanfaatan lebah hutan adalah dengan mengolah sarang lebah yang telah diambil madunya. Sebagai upaya dalam mengoptimalkan penggunaan lebah hutan adalah dengan memanfaatkan sarang lebah tersebut menjadi lilin terutama lilin beraroma terapi.

Minah dkk (2017) telah melakukan penelitian penggunaan sarang lebah untuk bahan baku lilin dengan menggunakan suhu $65^{\circ} \mathrm{C}$ dimana lilin yang dihasilkan layak dikomersialkan. Proses pembuatan lilin aromaterapi dari sarang lebah juga telah dilakukan oleh Sharma (2009), dengan penambahan minyak atsiri aroma kamboja dengan variasi 1\%, 2\%,3\%,4\%. Kondisi optimum yang dihasilkan yaitu pada penambahan minyak atsiri sebanyak $1 \%$ dengan waktu bakar selama 121 menit. Penelitian lain juga telah dilakukan oleh (Fitrah \& Boy, 2018) dengan hasil yang didapatkan ketahanan lilin yang berasal dari sarang lebah lebih baik dari lilin parafin hal ini dapat dilihat dari perbandingan titik leleh keduanya.

\section{MASALAH}

Lilin merupakan benda yang mudah kita jumpai dikehidupan sehari-hari. Lilin tidak hanya sebagai penerangan, kini lilin juga banyak digunakan sebagai medium aromaterapi serta benda dengan nilai seni yang tinggi. Aromaterapi adalah istilah modern yang dipakai untuk proses penyembuhan kuno yang menggunakan sari tumbuhan aromatik murni. Sarang lebah merupakan limbah yang belum dioptimalkan pemanfaatannya oleh petani lebah setelah pemanenan madu lebah. Sarang lebah mengandung kelenjar lilin yang dihasilkan oleh lebah tersebut. Kandungan lilin pada disarang lebah dapat digunakan sebagai alternatif bahan pembuat lilin aromaterapi dengan harga yang relatif murah. Lilin aromaterapi merupakan salah satu bentuk inovasi penggunaan lilin dalam pengobatan. Adanya tuntutan kesehatan maka dicari alternative dalam pembuatan lilin yang lebih baik bagi kesehatan,yaitu menggunakan sarang lebah (Hasanudin, 2003). Desa Sungai Pagar memiliki banyak potensi lebah hutan. Saat ini pemanfaatan lebah hutan di Desa Sungai Pagar hanya sebatas pengambilan madu lebah dan bekas sarang lebah belum dimanfaatkan. Rumusan masalah dari kegiatan ini adalah "Bagaimana pembuatan lilin aromaterapi menggunakan sarang lebah dan ekstrak lemon, sebagai inovasi pemanfaatan limbah sarang lebah di Desa Sungai Pagar Kecamatan Kampar Kiri Hilir ?"

Pelatihan dan pembuatan lilin aromaterapi perlu diinformasikan kepada masyarakat melalui kukerta terintegrasi yang merupakan salah satu program dari lembaga pengabdian kepada masyarakat Universitas Riau. Dimana Tim LPPM Universitas Riau dari Dosen pembimbing lapangan kukerta akan memberikan informasi kepada masyarakat dalam pembuatan sarang lebah menjadi lilin aromaterapi. Dengan demikian kegiatan pengabdian masyarakat ini diharapkan dapat mendukung program Kuliah Kerja Nyata Universitas Riau. 


\section{METODE PELAKSANAAN}

Kegiatan pengabdian kepada masyarakat ini telah dilaksanakan di kelurahan Sungai Pagar, Kecamatan Kampar Kiri Hilir, Kabupaten Kampar, Provinsi Riau. Pengabdian ini dilaksanakan dalam serangkaian kegiatan, antara lain penyuluhan, pelatihan dan pemasaran.

Kegiatan penyuluhan bertujuan untuk mensosialisasikan dan mengenalkan inovasi produk tersebut yaitu lilin aromaterapi dari sarang lebah kepada masyarakat Sei Pagar, selanjutnya dilaksanakan pelatihan. Pelatihan ini bertujuan untuk mengajak masyarakat Sei Pagar untuk terjun langsung membuat lilin aromaterapi tersebut, sehingga cara pembuatannya tersampaikan ke masyarakat Sei Pagar. Setelah itu dilaksanakan kegiatan pemasaran, dimana kegiatan ini bertujuan untuk menjelaskan rincian biaya yang digunakan untuk membuat produk lilin, dan memberikan informasi mengenai harga jual dan keuntungan yang didapatkan dari penjualan produk lilin. Selain itu, dalam kegiatan ini juga diberikan pengarahan mengenai cara pengemasan (packaging) produk lilin sehingga dapat meningkatkan nilai estetika dan nilai jual dari produk lilin aromaterapi tersebut.

\section{Strategi Kegiatan}

Kegiatan pengabdian kepada masyarakat ini akan dilakukan dengan strategi dukungan sosial (social support). Metode yang digunakan berupa pelatihan yang diberikan melalui ceramah dengan menggunakan media presentasi power point yang materinya berkaitan dengan topik/materi pelatihan, diskusi, demonstrasi, dan simulasi.

Dalam penerapan kegiatan pengabdian masyarakat dilakukan beberapa tahap diantaranya tahap pertemuan dengan masyarakat dan pembagian kelompok pelatihan serta mendata peminat yang ingin mengikuti pelatihan, kemudian dari hasil data peserta dilanjutkan tahap Pelatihan dan penyuluhan materi pelatihan pembuatan lilin aromaterapi kepada masyarakat. Tahap terakhir untuk melihat capaian terhadap hasil pelatihan dilakukan pantuan melalui evaluasi terhadap peserta.

\section{Langkah-langkah Kegiatan}

1. Melakukan pendekatan dengan instansi terkait, pimpinan kecamatan, tokoh masyarakat, Tim Penggerak PKK, kepala desa dan masyarakat kelurahan Sungai Pagar

2. Berkoordinasi dengan pimpinan kecamatan dan pihak-pihak terkait lainnya tentang jadwal pelaksanaan kegiatan.

3. Melakukan kerjasama dengan UKM petani madu sialang, yaitu Imbo Kaluang.

4. Melakukan sosialisasi dengan khalayak sasaran.

5. Persiapan undangan dan penyebaran undangan.

6. Persiapan alat-alat dan fasilitator untuk pelaksanaan kegiatan

7. Pelaksanaan Kegiatan Pengabdian berdasarkan bidang pengabdian.

8. Monitoring dan evaluasi kegiatan.

\section{Evaluasi Kegiatan}

Evaluasi keberhasilan kegiatan pengabdian dapat diketahui dari ketercapaian atau efektifitas tujuan pelaksanaan kegiatan. Untuk mendukung tercapainya keberhasilan tersebut, Tim Pengabdian memberikan sejumlah peralatan dan bahan terkait dalam melaksanakan pembuatan lilin aromaterapi tersebut dengan tujuan untuk mendukung masyarakat Sungai Pagar dalam mengolah sarang lebah tersebut menjadi lilin aromaterapi menggunakan ekstrak lemon.

Kegiatan ini bekerjasama dengan UKM madu sialang terbesar di Sungai Pagar, yaitu Imbo Kaluang sehingga memudahkan dalam pengembangan keahlian masyarakat Sungai Pagar untuk membentuk industri skala rumah tangga (home industry) terkait dengan pembuatan lilin aromaterapi. Dalam penerapan kegiatan pengabdian masyarakat dilakukan beberapa tahap diantaranya tahap pertemuan dengan masyarakat dan pembagian kelompok pelatihan serta mendata peminat yang ingin mengikuti pelatihan, kemudian dari hasil data peserta dilanjutkan tahap Pelatihan dan penyuluhan materi pelatihan pembuatan lilin aromaterapi kepada masyarakat. Tahap terakhir untuk melihat capaian terhadap hasil pelatihan dilakukan diskusi dan wawancara.

\section{Bahan dan Alat Proses Pembuatan}

\section{Bahan:}

Sarang lebah $5 \mathrm{~kg}$, parafin padat $2 \mathrm{~kg}$, sumbu lilin, minyak atsiri lemon secukupnya, pewarna secukupnya dan akuades (air biasa) secukupnya. 


\section{Alat:}

Panci besar dan kecil, saringan, sendok besar dan kecil, gelas (wadah) tempat lilin, kompor gas dan tabung gas.

\section{Proses Pembuatan Lilin Aromaterapi}

Sarang lebah dimasukkan ke dalam panci dengan berat $5 \mathrm{~kg}$ kemudian dipanaskan menggunakan hot plate (pemanas) pada suhu $50^{\circ} \mathrm{C}$ selama $1,5 \mathrm{jam}$. Sarang lebah yang telah mencair tersebut disaring menggunakan saringan untuk memisahkan kotoran dengan cairan setelah itu dipanaskan kembali menggunakan hot plate (pemanas) hingga mencair. Selanjutnya sarang lebah yang sudah mencair tersebut dimasukkan kedalam cetakan kemudian teteskan Ekstrak Lemon sebanyak 12 tetes kedalam cetakan setelah itu pasang sumbu sumbu pada cetakan lilin, ditunggu hingga mengeras. Pelakuan yang sama dilakukan pada saat pembuatan lilin aroma terapi menggunakan parafin.

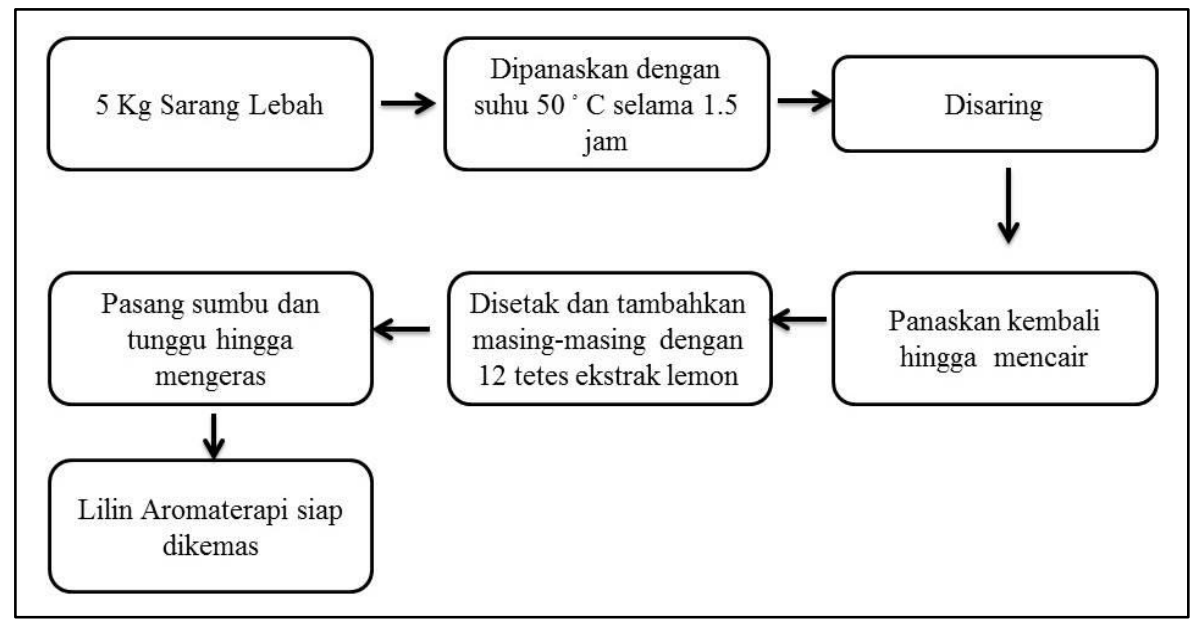

Gambar 1. Skema Pembuatan Lilin Aroma Terapi dari Sarang Lebah Murni

\section{HASIL DAN PEMBAHASAN}

Kegiatan ini dilaksanakan oleh Tim Pengabdian berupa sosialisasi atau penyuluhan, pelatihan pembuatan pelatihan pengemasan dan pelatihan publikasi di Kelurahan Sungai Pagar, Kecamatan Kampar Kiri Hilir, Kabupaten Kampar, Provinsi Riau. Penyelengaraan kegiatan ini bekerjasama dengan UKM madu sialang di Sungai Pagar yaitu Imbo Kaluang. Pengabdian ini dilaksanakan dalam serangkaian kegiatan, antara lain penyuluhan, pelatihan dan pemasaran.

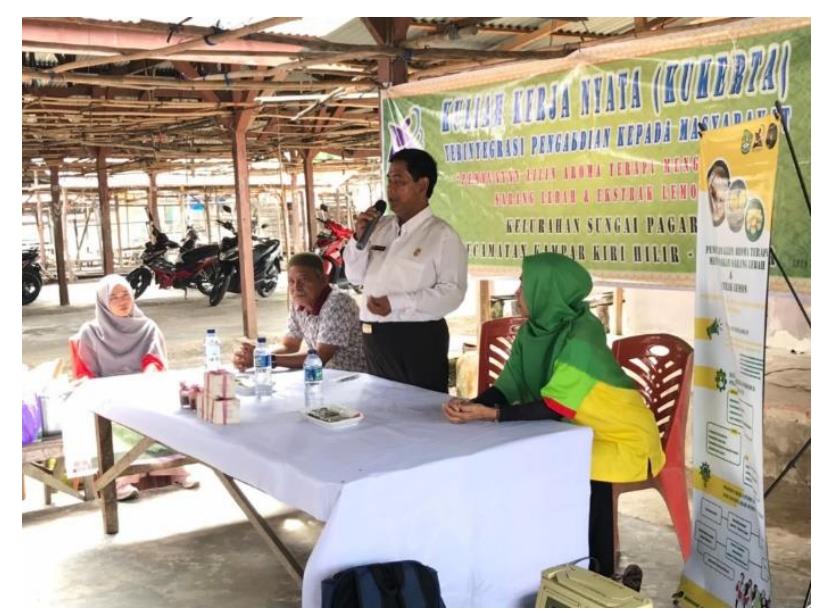

Gambar 2. Pembukaan Pelatihan Pembuatan Lilin Aromaterapi oleh Bapak Agus Wiyana, SPd.i selaku Kepala Kelurahan Sungai Pagar 
Kegiatan pertama yaitu penyuluhan bertujuan untuk mensosialisasikan dan mengenalkan inovasi produk tersebut yaitu lilin aromaterapi dari sarang lebah kepada masyarakat Sei Pagar, selanjutnya dilaksanakan pelatihan. Pelatihan ini bertujuan untuk mengajak masyarakat Sei Pagar untuk terjun langsung membuat lilin aromaterapi tersebut, sehingga cara pembuatannya tersampaikan ke masyarakat Sei Pagar. Dalam pelatihan ini, masyarakat Sei Pagar diberikan arahan mulai dari persiapan bahan-bahan yaitu sarang lebah, parafin, pewarna, ekstrak lemon dan pernak-pernik lainnya, persiapan peralatan sampai proses pembuatannya. Setelah itu dilaksanakan kegiatan pemasaran, dimana kegiatan ini bertujuan untuk menjelaskan rincian biaya yang digunakan untuk membuat produk lilin, dan memberikan informasi mengenai harga jual dan keuntungan yang didapatkan dari penjualan produk lilin. Selain itu, dalam kegiatan ini juga diberikan pengarahan mengenai cara pengemasan (packaging) produk lilin sehingga dapat meningkatkan nilai estetika dan nilai jual dari produk lilin aromaterapi tersebut. Tim Pengabdian Universitas Riau menamakan produk lilin tersebut yaitu "Madulin" berarti madu lilin.

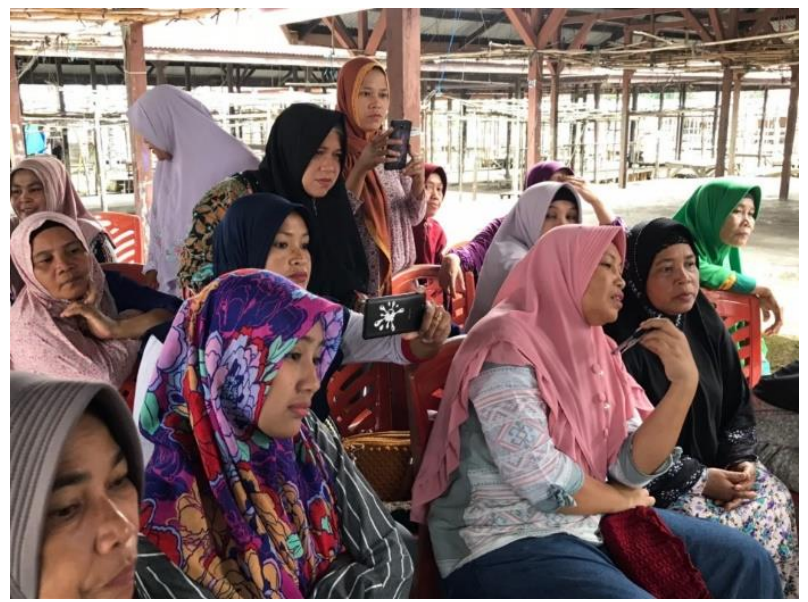

Gambar 3. Peserta Pelatihan Pembuatan Lilin Aromaterapi menggunakan Sarang Lebah dan Ekstrak Lemon

Secara umum, pelaksanaan kegiatan pengabdian kepada masyarakat ini berjalan dengan lancar dan tidak adanya kendala. Hal ini dapat dilihat dari tanggapan peserta atau masyarakat yang hadir sangat positif dan mengharapkan kerjasama selanjutnya tentang penerapan teknologi tepat guna lainnya yang dapat memberikan manfaat bagi masyarakat.

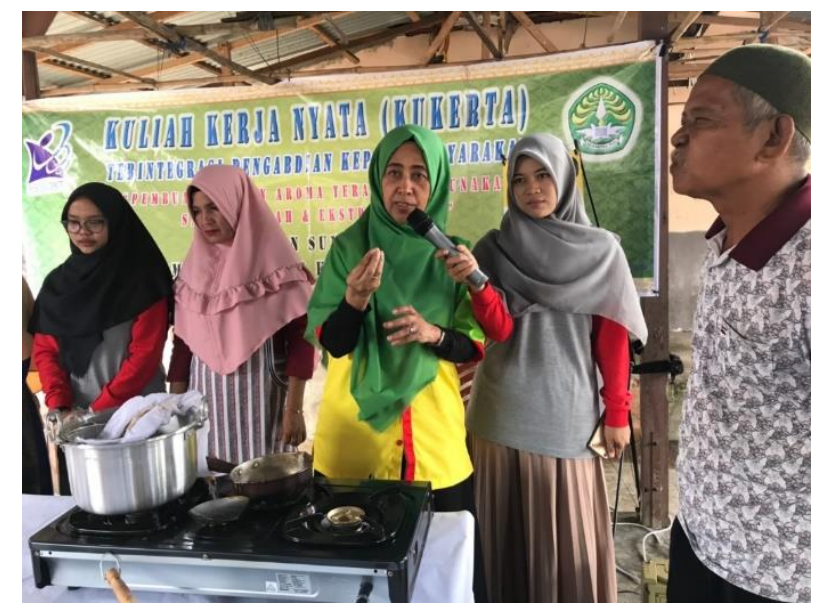

Gambar 4. Penjelasan mengenai pembuatan lilin aromaterapi oleh Ibu Dra. Silvia Reni Yenti, M.Si selaku Dosen Pendamping Lapangan (DPL) dan Ketua Tim Pengabdian

Dalam melaksanakan kegiatan pengabdian ini, Tim Pengabdian telah bekerjasama dengan UKM Madu Sialang di Sungai Pagar yaitu Imbo Kaluang yang bertujuan untuk memudahkan dalam pengembangan keahlian masyarakat Sungai Pagar untuk membentuk industri skala rumah tangga (home industry) terkait dengan pembuatan lilin aromaterapi. Tim Pengabdian memberikan sejumlah peralatan dan bahan terkait dalam 
melaksanakan pembuatan lilin aromaterapi tersebut dengan tujuan untuk mendukung masyarakat Sungai Pagar dalam mengolah sarang lebah tersebut menjadi lilin aromaterapi menggunakan ekstrak lemon. Dengan diberikannya sejumlah peralatan dan bekerjasama dengan UKM Imbo Kaluang, diharapkan kedepannya masyarakat Sungai Pagar dapat dengan mudah mengolah sarang lebah tersebut menjadi produk lilin aromaterapi sehingga dapat membantu dalam menunjang perekenomian masyarakat Sungai Pagar.

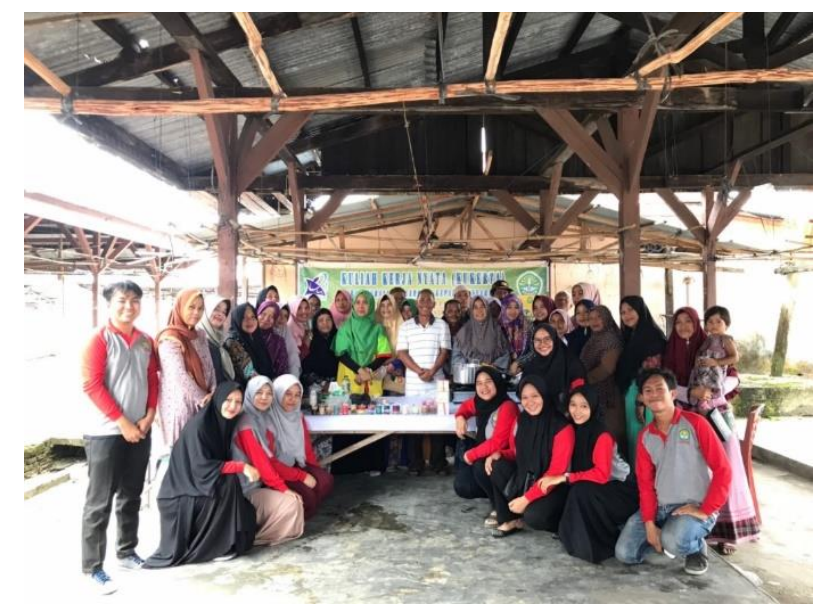

Gambar 5. Foto bersama Masyarakat Sungai Pagar
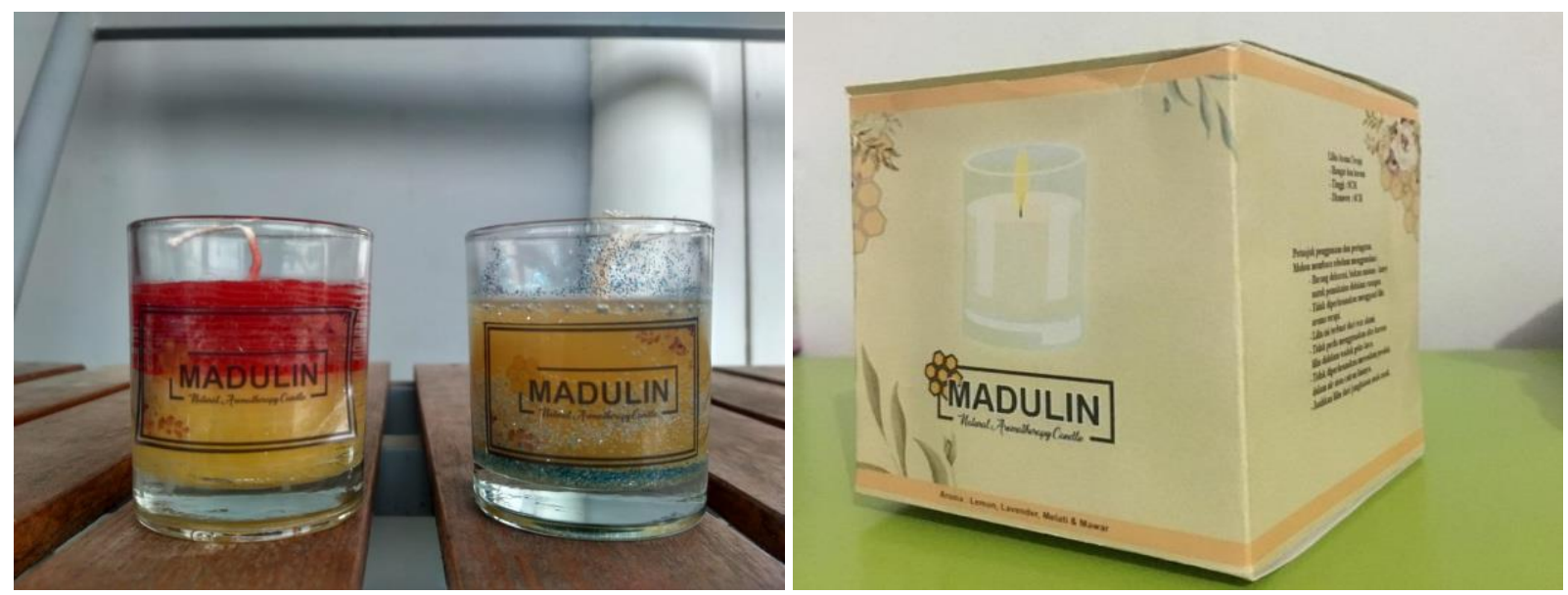

Gambar 6. Produk Lilin Aromaterapi dan Kemasan Lilin Aromaterapi "Madulin"

\section{KESIMPULAN}

Berdasarkan kegiatan pengabdian masyarakat yang telah dilaksanakan, kegiatan berjalan dengan sangat lancar. Hal ini dapat dilihat dari respon positif dari peserta atau masyarakat yang mengikuti kegiatan ini dan adanya kerjasama dengan UKM Madu Sialang di Sungai Pagar yaitu Imbo Kaluang. Selain itu, Tim Pengabdian memberikan sejumlah peralatan kepada Masyarakat Sungai Pagar untuk menunjang dalam pembuatan lilin aromaterapi tersebut. Dengan adanya kegiatan ini, pengolahan sarang lebah dapat dimanfaatkan secara optimal menjadi produk yang bernilai tinggi yaitu produk lilin aromaterapi.

Diharapkan dengan adanya kegiatan pengabdian ini, dapat meningkatkan kualitas sumber daya manusia yang meliputi keahlian dan kemampuan serta dapat membantu dalam menunjang perkenomian masyarakat Sungai Pagar. 


\section{DAFTAR PUSTAKA}

Adwyah. 2006. Pengolahan dan Pengawetan Ikan. Jakarta: Bumi Aksara.

Afrisanti, D. W. 2010. Kualitas Kimia dan Organoleptik Nugget Daging Kelinci dengan Penambahan Tepung Tempe. Skripsi Program Studi Peternakan. Fakultas Pertanian, Universitas Sebelas Maret, Surakarta.

Badan Standarisasi Indonesia. 2002. Standart Mutu Nugget, SNI.01-6638-2002. Jakarta: Badan Standarisasi Nasional.

Ginting. 2015. Penggunaan Bahan Pengisi pada Nugget. Jurnal Agribisnis.

Haris, R. S., \& E. Karmas. 1989. Evaluasi Gizi pada Pengolahan Bahan Pangan. Bandung: Institut Teknologi Bandung.

Maghfiroh, I. 2000. Pengaruh Penambahan Bahan Pengikat Terhadap Karakteristik Nugget Ikan Patin (Pangasius hypohthalamus). Skripsi Program Studi Teknologi Hasil Perikanan. Fakultas Perikanan, Institut Pertanian Bogor, Bogor.

Rusliadi, I. Putra, M. Fauzi, N. A. Pamukas, \& H. Masjudi. 2018. Pengembangan mata pencaharian alternatif bagi nelayan melalui kegiatan budidaya ikan dengan teknologi bioflok di Kampung Sungai Kayu Ara. Riau Journal of Empowerment 1(2): 61-65. https://doi.org/10.31258/raje.1.2.8

Saleh, M., K. Prana, \& S. Hartatik. 2002. Dokumen Tepat Guna. UPT Perpustakaan Bogor, Institut Pertanian Bogor, Bogor.

Sianturi, R. 2000. Kandungan Gizi dan Uji Palatabilitas Nugget Daging Sapi dengan Kacang Tanah (Arachis hypogeae L) sebagai Bahan Pencampur. Skripsi Sarjana Jurusan Ilmu Produksi Ternak, Fakultas Peternakan, Institut Pertanian Bogor, Bogor.

Syahza, A., D. Bakce, \& B. Asmit. 2018. Increasing the awareness of palm oil plantation replanting through farmers training. Riau Journal of Empowerment 1(1): 1-9. https://doi.org/10.31258/raje.1.1.1

Tumion, F. F., \& Hastuti, N. D. 2017. Pembuatan Nugget Ikan Lele (Clarias Sp) dengan Variasi Penambahan Tepung Terigu. Jurnal Agromix, 11(1): 27-38.

Yenti, S. R. 2017. Pelatihan Teknologi Tepat guna dalam Pembuatan Abon Ikan di Penghuluan Bagan Punak Meranti Kecamatan Bangko Kabupaten Rokan Hilir. Laporan Penelitian, Dana DIPA UNRI. Universitas Riau, Pekanbaru. 